\title{
Y-STR diversity and ethnic admixture in White and Mulatto Brazilian population samples
}

\author{
Luzitano Brandão Ferreira, Celso Teixeira Mendes-Junior, Cláudia Emília Vieira Wiezel, \\ Marcelo Rizzatti Luizon and Aguinaldo Luiz Simões \\ Departamento de Genética, Faculdade de Medicina de Ribeirão Preto, Universidade de São Paulo, \\ Ribeirão Preto, SP, Brazil.
}

\begin{abstract}
We investigated 50 Mulatto and 120 White Brazilians for the Y-chromosome short tandem repeat (Y-STR) markers (DYS19, DYS390, DYS391, DYS392 and DYS393) and found 79 different haplotypes in the White and 35 in the Mulatto sample. Admixture estimates based on allele frequencies showed that the admixture of the white sample was 89\% European, 6\% African and 5\% Amerindian while the Mulatto sample was 93\% European and 7\% African. Results were consistent with historical records of the directional mating between European males and Amerindian or African females.
\end{abstract}

Key words: Brazil, Mulatto, White, Y-STR.

Received: September 26, 2005; Accepted: March 15, 2006.

The Brazilian population is a result of interethnic crosses of Europeans, Africans and Amerindians, and is one of the most heterogeneous populations in the world. When the first European colonizers arrived (1500 AD), 1-5 million Amerindians already lived in the region that now is known as Brazil (Salzano and Callegari-Jacques, 1988). Before 1820, European colonization was almost exclusively composed of Portuguese while between 1820 and 1975 the great majority of immigrants were from Portugal and Italy, followed by a small number by people from Spain, Germany, Syria and Japan (Carvalho-Silva et al., 2001). Between the $16^{\text {th }}$ and 19th centuries approximately 3.5 million Africans were brought as slaves to Brazil, coming mainly from West, West-Central and Southeast Africa (Curtin, 1969). The colonization of Brazil involved mostly European men, many of whom produced children with Amerindian and African females.

Although the classification of races is wrong from genetic standpoint (Templeton, 1998), Brazilians are classified for census purposes based on color. According to the last Brazilian government census of the 170 million Brazilians, 84 million were males, of which $52 \%$ were White, $39 \%$ were Brown, $6 \%$ were Black and $3 \%$ were classified in other categories (IBGE, 2000). Mulatto is the term commonly used in Brazil to designate the offspring result from

Send correspondence to Aguinaldo Luiz Simões. Departamento de Genética, Faculdade de Medicina de Ribeirão Preto, Universidade de São Paulo, Av. Bandeirantes 3900, 14049-900 Ribeirão Preto, SP, Brazil. E-mail: alsimoes@fmrp.usp.br. the union of White and Black people. We used five Ychromosome short tandem repeat (Y-STR) markers, recognized as good markers for population studies, to investigate genetic polymorphism and ethnic admixture in White and Mulatto Brazilian population samples.

We investigated 170 healthy, unrelated, individuals seeking paternity investigation at the Ribeirão Preto University Hospital, in the city of Ribeirão Preto, São Paulo state, Southeastern Brazil. The race of the individuals in the sample was determined based on their biomedical records, 120 individuals being White and 50 Mulatto, from Ribeirão Preto and the surrounding towns.

We assessed the Y-STR loci DYS19, DYS390, DYS391, DYS392 and DYS393 (Kayser et al., 1997) using blood samples taken from the individuals in our sample, DNA being extracted by an adaptation of the protocol of Higuchi (1989). The PCR reactions were performed according to the conditions described by Kayser et al. (1997) and products separated using $10 \%$ denaturing polyacrylamide gel electrophoresis and visualized by silver staining (Sanguinetti et al., 1994). Allele designations were determined by comparison of the sample fragments with those of control DNA samples previously cloned and sequenced.

Allele and haplotype frequencies were estimated by the gene counting method and gene and haplotype diversities calculated using the ARLEQUIN software version 2.000 (Schneider et al., 2000). Admixture proportions, based on allelic frequencies, were calculated by the gene identity method (Chakraborty, 1975) using the ADMIX3 
program. Parental populations used in this study were from Portugal (González-Neira et al., 2000; Carvalho et al., 2003), Italy (Biondo et al., 1998), Guinea-Bissau (Rosa et al., 2006), Angola (Corte-Real et al., 2000), Mozambique (Pereira et al., 2002) and South American Indians (Rodriguez-Delfin et al, 1997; Tarazona-Santos et al, 2001). This study was approved by the Research Ethics Committee of the Ribeirão Preto University Hospital, Ribeirão Preto School of Medicine, University of São Paulo.

New alleles were not found, the frequencies of those found being shown in Table 1. A total of 79 (62 unique) different haplotypes were identified in the White and 35 (27 unique) in the Mulatto sample. The haplotype diversity was $0.9822 \pm 0.0053$ in the White and $0.9747 \pm 0.0118$ in the Mulatto sample. The most frequent haplotype 14-24-11-
13-13 (DYS19-DYS390-DYS391-DYS392-DYS393) was encountered in $11(9 \%)$ White and $6(17 \%)$ of Mulatto individuals. The next most frequent haplotype (14-24-10-1313) differed from the most frequent haplotype by only a single DYS391 repeat and was shared by $9(7 \%)$ White and 5 (14\%) Mulatto individuals. Together, the two most frequent haplotypes accounted for $26 \%$ of the White and $31 \%$ of the Mulatto sample.

The Mulatto population samples analyzed for paternal lineage in the present study showed $0.93 \pm 0.01$ of European and $0.07 \pm 0.01$ of African component (Table 2). The European contribution was different to that verified by HLA. polymorphisms in the State of Paraná, where the relative contribution was $0.42 \pm 0.06$ (Probst et al., 2000). As observed in Mulattos, previous studies with White Brazil-

Table 1 - Allele frequencies for five Y-STR loci in White and Mulatto samples from the State of São Paulo, Brazil.

\begin{tabular}{|c|c|c|c|c|c|c|c|c|c|c|}
\hline \multirow[t]{2}{*}{ Alelles } & \multicolumn{2}{|c|}{ DYS19 } & \multicolumn{2}{|c|}{ DYS390 } & \multicolumn{2}{|c|}{ DYS391 } & \multicolumn{2}{|c|}{ DYS392 } & \multicolumn{2}{|c|}{ DYS393 } \\
\hline & $\mathrm{W}$ & $\mathrm{M}$ & $\mathrm{W}$ & M & W & M & W & $\mathrm{M}$ & W & $\mathrm{M}$ \\
\hline 9 & & & & & 0.116 & 0.020 & & & & \\
\hline 10 & & & & & 0.576 & 0.620 & 0.083 & 0.040 & & \\
\hline 11 & & & & & 0.292 & 0.340 & 0.376 & 0.340 & & \\
\hline 12 & & & & & 0.016 & 0.020 & 0.050 & 0.020 & 0.158 & 0.140 \\
\hline 13 & 0.175 & 0.140 & & & & & 0.433 & 0.500 & 0.676 & 0.780 \\
\hline 14 & 0.548 & 0.520 & & & & & 0.033 & 0.080 & 0.141 & 0.080 \\
\hline 15 & 0.215 & 0.240 & & & & & 0.025 & 0.020 & 0.025 & \\
\hline 16 & 0.042 & 0.080 & & & & & & & & \\
\hline 17 & 0.020 & 0.020 & & & & & & & & \\
\hline 21 & & & 0.066 & 0.060 & & & & & & \\
\hline 22 & & & 0.100 & 0.240 & & & & & & \\
\hline 23 & & & 0.210 & 0.160 & & & & & & \\
\hline 24 & & & 0.517 & 0.420 & & & & & & \\
\hline 25 & & & 0.008 & 0.040 & & & & & & \\
\hline 26 & & & 0.066 & 0.080 & & & & & & \\
\hline 27 & & & 0.033 & & & & & & & \\
\hline $\mathrm{n}$ & 120 & 50 & 120 & 50 & 120 & 50 & 120 & 50 & 120 & 50 \\
\hline
\end{tabular}

W: White; M: Mulatto; n: number of individuals.

Table 2 - Parental contribution in Brazilian samples classified as White and Mulatto.

\begin{tabular}{|c|c|c|c|c|c|c|}
\hline \multirow[t]{2}{*}{ Identification } & \multirow[t]{2}{*}{ Populations } & \multirow[t]{2}{*}{ Genetic marker } & \multicolumn{3}{|c|}{ Parental contribution } & \multirow[t]{2}{*}{ Ref } \\
\hline & & & European & African & Amerindian & \\
\hline \multirow[t]{6}{*}{ White } & Brazil & Y-chromosome UEPs & $0.97 \pm 0.00$ & $0.03 \pm 0.00$ & $0.00 \pm 0.00$ & 1 \\
\hline & São Paulo (southeastern Brazil) & Y-chromosome STRs & $0.89 \pm 0.01$ & $0.06 \pm 0.01$ & $0.05 \pm 0.01$ & Ps \\
\hline & Rio Grande do Sul (southern Brazil) & Y-chromosome UEPs & $1.00 \pm 0.00$ & $0.00 \pm 0.00$ & $0.00 \pm 0.00$ & 2 \\
\hline & Paraná (southern Brazil) & HLA polymorphisms & $0.81 \pm 0.07$ & $0.12 \pm 0.06$ & $0.07 \pm 0.01$ & 3 \\
\hline & Brazil & mtDNA & $0.39 \pm 0.00$ & $0.28 \pm 0.00$ & $0.33 \pm 0.00$ & 4 \\
\hline & Rio Grande do Sul (southern Brazil) & mtDNA & $0.48 \pm 0.00$ & $0.16 \pm 0.00$ & $0.36 \pm 0.00$ & 2 \\
\hline \multirow[t]{2}{*}{ Mulatto } & São Paulo (southeastern Brazil) & Y-chromosome STRs & $0.93 \pm 0.01$ & $0.07 \pm 0.01$ & $0.00 \pm 0.00$ & Ps \\
\hline & Paraná (southern Brazil) & HLA polymorphisms & $0.42 \pm 0.06$ & $0.49 \pm 0.06$ & $0.09 \pm 0.01$ & 3 \\
\hline
\end{tabular}

Ref: References; Ps: Present study; 1- Carvalho-Silva et al., 2001; 2- Marrero et al., 2005; 3- Probst et al., 2000; 4- Alves-Silva et al., 2000. 
ian populations have demonstrated that the degree of admixture varied depending on the genetic marker used. While the Y-chromosome lineages in White samples were almost exclusively from European origin (Carvalho-Silva et al., 2001), mtDNA showed similar European, African and Amerindian contributions (Alves-Silva et al., 2000). In our study, the admixture estimate for the White sample was $0.89 \pm 0.01$ European, $0.06 \pm 0.01$ African and $0.05 \pm 0.01$ Amerindian. As shown in Table 2, the high European component is similar to that found in the Brazilian Y-chromosome study carried out by Carvalho-Silva et al. (2001) and in the study by Marrero et al. (2005) who investigated a population sample from the southernmost Brazilian state of Rio Grande do Sul which has a predominantly White population, but greater than that verified with HLA polymorphisms (Probst et al., 2000).

Ethnic admixture based on five Y-STR loci in the present study showed a high predominance of the European component in the White and Mulatto samples. These results are consistent with historical records of the directional mating between European males and Amerindian or African females during the colonization of Brazil.

\section{Acknowledgments}

Many thanks to Maria do Carmo Tomitão Canas and Ana Lúcia Pimentel for their excellent technical assistance. This work was supported by the Brazilian Agencies CNPq, CAPES and FAPESP, Brazil.

\section{References}

Alves-Silva J, Santos MS, Guimarães PEM, Ferreira ACS, Bandelt H, Pena SDJ and Prado VF (2000) The ancestry of Brazilian mtDNA lineages. Am J Hum Genet 67:444-461.

Biondo R, Cagliá A, Asili P, D'Agostaro D’Agostino G and Spinella A (1998) Typing of 20 Y-chromosome STRs in the Italian population. For Sci Int S135-S138.

Carvalho M, Anjos M, Andrade L, Lopes V, Santos MV, Gamero J, Real FC and Vide M (2003) Y-chromosome STR haplotypes in two populations samples: Azores Islands and Central Portugal. For Sci Int 134:29-35.

Carvalho-Silva D, Santos FR, Rocha J and Pena SDJ (2001) The phylogeography of Brazilian y-chromosome lineages. Am J Hum Genet 68:281-286.

Chakraborty R (1975) Estimation of race admixture - A new method. Am J Phys Anthropol 42:507-511.

Corte-Real F, Andrade L, Carvalho M, Anjos MJ, Gamero J, Vieira DN, Carracedo A and Vide MC (2000) Comparative analysis of STR data for Portuguese spoken countries. Prog Forensic Genet 8:212-214.
Curtin PD (1969) The Atlantic Slave Trade: A Census. University of Winsconsin Press, Madison, 312 pp.

González-Neira A, Gusmão L, Brión M, Lareu MV, Amorim A and Carracedo A (2000) Distribution of Y chromosome STR defined haplotypes in Iberia. For Sci Int 110:117-126.

Higuchi R (1989) Simple and rapid preparation of samples for PCR. In: Erlich HA (ed) PCR Technology: Principles and Applications for DNA Amplification. Stocton Press, New York, pp 31-38.

Instituto Brasileiro de Geografia e Estatística (IBGE), www.ibge. gov.br.

Kayser M, Knijff P, Dieltjes P, Krawczak M, Nagy M, Zerjal T, Pandya A, Tyler-Smith C and Roewer L (1997) Applications of microsatellite-based Y chromosome haplotyping. Electrophoresis 18:1602-1607.

Marrero AR, Leite FPN, Carvalho BA, Peres LM, Kommers TC, Cruz IM, Salzano FM, Ruiz-Linares A, Silva-Junior WA and Bortolini MC (2005) Heterogeneity of the genome ancestry of individuals classified as White in the State of Rio Grande do Sul, Brazil. Am J Hum Biol 17:496-506.

Pereira L, Gusmão L, Alves C, Amorim A and Prata MJ (2002) Bantu and European Y-lineages in Sub-Saharan África. Ann Hum Genet 66:369-378.

Probst CM, Bompeixe EP, Pereira NF, Dalalio MMO, Visentainer JEL, Tsuneto LT and Petzl-Erler ML (2000) HLA polymorphism and evaluation of European, African and Amerindian contribution to the White and Mulatto populations from Paraná, Brazil. Hum Biol 72:597-617.

Rosa A, Ornelas C, Brehm A and Villems R (2006) Population data on 11 Y-chromosome STRs from Guiné-Bissau. For Sci Int 157:210-217

Rodriguez-Delfin L, Santos SEB and Zago MA (1997) Diversity of the human Y chromosome of South American Amerindians: A comparison with Blacks, Whites and Japanese from Brazil. Ann Hum Genet 61:439-448.

Sanguinetti CJ, Dias-Neto E and Simpson AJ (1994) Rapid silver straining and recovery of PCR products separated on polyacrylamide gels. Biotechniques 17:914-921.

Salzano FM and Callegari-Jacques SM (1988) South Amerindian Indians. A Case Study in Evolution. Clarendon Press, Oxford, $259 \mathrm{pp}$.

Schneider S, Roessli D and Excoffier L (2000) Arlequin ver. 2.000: A software for population genetics data analysis. Genetics and Biometry Laboratory, University of Geneva, Switzerland.

Tarazona-Santos E, Carvalho-Silva DR, Pettener D, Luiselli D, Stefano GF, Labarga CM, Rickards O, Tyler-Smith, Pena SDJ and Santos FR (2001) Genetic differentiation in South Amerindians is related to environmental and cultural diversity: Evidence from the Y chromosome. Am J Hum Genet 68:1485-1496.

Templeton AR (1998) Human races: A genetic and evolutionary perspective. Am Anthropol 100:632-650.

Associate Editor: Francisco Mauro Salzano 